\title{
Incidence of Calf Morbidity and Its Predictors in North Shewa, Amhara, Ethiopia
}

\author{
Rahma Mohammed, Hailemariam Kefyalew, and Dawit Kassaye
}

College of Veterinary Medicine, Haramaya University, Dire Dawa, Ethiopia

Correspondence should be addressed to Dawit Kassaye; dawitkassaye@gmail.com

Received 17 September 2019; Accepted 17 January 2020; Published 11 February 2020

Academic Editor: Antonio Ortega-Pacheco

Copyright ( 92020 Rahma Mohammed et al. This is an open access article distributed under the Creative Commons Attribution License, which permits unrestricted use, distribution, and reproduction in any medium, provided the original work is properly cited.

Calf morbidity is an important productivity factor that results in huge economic losses in the success of livestock production in Ethiopia. However, there is no robust information on its rate and its predictors in the mixed crop livestock production system as most studies are targeted to intensive dairy farms. A longitudinal study design was conducted from December 2018 to April 2019 in Siyadeber and Wayu districts of Amhara region, Ethiopia. A total of 135 apparently healthy calves were enrolled from randomly selected fifty-fifty households in three Kebeles of the district, namely, Gash-amba, Siyadeber, and Wale-deneba. A pretested structured questionnaire was used to collect data about the potential risk factors upon the face-to-face interview made with the owners. Calves were monitored for the incidence of morbidity in a weekly visit basis, and any clinical abnormalities were recorded on registries. The chi-square and Fisher's exact test followed by Generalized Linear Models for binomial family extensions for risk estimate were run, and a $p$ value $<0.05$ was considered statistically significant. In this study, the overall incidence rate of calf morbidity among under six months of age was 388 calves per 100,000 days of follow-up, with a cumulative incidence of $34.1 \%$ (95\% CI: 26.1-42.7). Calf diarrhea, pneumonia, septicemia, dehydration, and navel ill were the encountered health problems consecutively. Among the potential risk factors, calves from Siyadeber Kebele (RR =2.11, 95\% CI: 1.13-3.94), calves housed with other livestock $(\mathrm{RR}=2.05,95 \% \mathrm{CI}: 1.10-3.80)$, housed with their dam $(\mathrm{RR}=1.92,95 \% \mathrm{CI}: 1.20-3.05)$, without bedding $(\mathrm{RR}=1.89$, 95\% CI: 1.20-2.94), and calves whose dam age ranges from 5 to 8 years ( $R R=1.87,95 \%$ CI: 1.05-3.35) were found to be predictors of calf morbidity. In general, the high calf morbidity rates established in this study together with the alarming predictors of calf morbidity entail attention by the concerning bodies on proper management and improved health care so as to reduce the calf morbidity.

\section{Introduction}

Ethiopia has the largest livestock inventories in Africa [1], and livestock production plays an important role in the national economy as well as in the socioeconomic development of millions of rural households. This can be explained in terms of food production, supply of inputs and services for crop production, raw material for agro-industry, cash income and export earning, saving and investment, and its role as a generator of employment. It accounts for about $19 \%$ of growth domestic product (GDP) and 20\% of the total export earnings [2]. The livestock sector is pertinent to sustainable food security and poverty reduction in the country. About $85 \%$ to $90 \%$ of mixed crop-livestock farmers and 21.6 million agro-pastoralists and pastoralists depend on livestock as a major economic activity for their livelihoods [3]. However, the production system is severely affected due to the low genetic quality of local breeds, poor nutrition, animal health problems, poor husbandry, and poor infrastructure $[4,5]$.

The morbidity and mortality of young stocks in Africa, including Ethiopia, indicate high rate both in the subsistence and market-oriented production systems [6]. Studies of calf mortality on smallholder farms indicate preweaning and early postweaning mortality rates in the range of $15 \%$ to $25 \%$. There is also high morbidity and mortality of calf in Ethiopia [7-9]. The annual direct losses from ruminant mortality are generally estimated at about $8 \%$ to $10 \%$ of the 
cattle herd, $14 \%$ to $16 \%$ of the sheep flock, and $11 \%$ to $13 \%$ of the goat flock. Young stock mortalities constitute the larger share of constraints to herd expansion and genetic improvement [6].

Calf morbidity and mortality are problems of major concern in all countries where cattle are raised under extensive husbandry practices [10], and the problem is more acute in developing countries due to bad calf management practices [11]. In Ethiopia, 30\% preweaning calf mortality rate is reported in mixed crop-livestock production systems in the Amhara Region [9] and 18\% mortality rate is found in market-oriented dairy farms in Central Ethiopia [8]. The productivity of cattle depends largely on their reproductive performance and the survival of calves $[12,13]$. Neonatal calf mortality is the most important constraint in young stock and accounted for $84 \%$ of total mortality [14].

Different authors reported that there is a wide range of calf morbidity and mortality levels in Ethiopia [7-9, 15, 16]. Calf health care is generally dependent to a great extent on management and hygiene practices, as majority of calf diseases arise as a result of poor management [7]. The disease that causes high morbidity and mortality of calves are the results of the complex interaction of the management practices, the environment, infectious agents, and the animal itself. Mortality of neonates of ruminants is mainly attributed to conditions like diarrhea and pneumonia associated with poor housing, hygiene, and nutrition [16]. Diarrhea in the neonatal period and pneumonia in older calves are known to be responsible for most of calf hood morbidity and mortality [17-19]. Similar findings were reported from Ethiopia [7-9, 15, 16]. Different researchers have investigated numerous determinant factors in calf morbidity and mortality $[8,19-24]$. By far, the greatest factor contributing to mortality of preweaned calves is failure of passive transfer (FTP), associated with $39 \%$ to $50 \%$ of preweaned calf mortality [25]. Different management and environmental factors such as colostral feeding, housing, calving assistance, production system, herd size, season, and hygiene of microenvironment is reported to affect significantly calf morbidity and mortality [2].

In Ethiopia there are some studies on calf morbidity and mortality $[8,9,15,16,26,27]$, though most of them were focused either on intensive dairy farms or ranches. But, in a mixed production system of the Amhara region, specifically in Siyadeber and Wayu district, there is no information available about the incidence of calf morbidity with epidemiological analysis of risk factors. Therefore, the present study is aimed to estimate the incidence of calf morbidity and its predictors in mixed production system at Siyadeber and Wayu districts of the Amhara region, Ethiopia.

\section{Materials and Methods}

2.1. Study Area and Period. The study was conducted from December 2018 to April 2019, at Siyadeber and Wayu Woreda, North showa zone of Amhara regional state in one of the highland areas of Ethiopia. The district is located approximately $129 \mathrm{~km}$ North East of Addis Ababa and $47 \mathrm{~km}$ North East of Debre Brhan at $9^{\circ} 45^{\prime} 29.33^{\prime \prime} \mathrm{N}$ latitude, $39^{\circ} 11^{\prime} 36.73^{\prime \prime}$ E longitude and an altitude of 1900 meter above sea level (Figure 1). Its temperature ranges from $10^{\circ} \mathrm{C}$ to $20^{\circ} \mathrm{C}$. The area receives mean annual rainfall of $900 \mathrm{~mm}$. Siyadeber and Wayu is bordered on south by Oromia Region, on West by Ensaro, on the North by Moretina Jiru, and on the East by Basona Werena. It has 13 Kebeles and one town Kebele. The livelihood of the people in this woreda mainly depends on the agriculture. The predominant production system in the areas is mixed crop-livestock farming, and cattle are the most important livestock species reared in these areas [28].

2.2. Study Design. A prospective cohort study from December 2018 to April 2019 was used to estimate the incidence of calf morbidity and assess the potential predictors of calf morbidity in the mixed production system.

\subsection{Animal Population}

2.3.1. Source Population and Study Animal. All apparently healthy under six months of calves up on physical and clinical examination, that were available in a household with a livestock and mixed crop production system in Siyadeber and Wayu district were considered as source population. Hence, clinically healthy calves of under six months of age up on thorough physical and clinical examination, that were available during the study period, were considered as a study animal population in which the study was conducted.

A calf owner who was willing to participate in the study and practice livestock-crop mixed production system in the area, as well as apparently healthy calves of under six months of age up on physical and clinical examination was included in the study. However, those apparently healthy calves with poor body condition score, household with calf who faced any social crises such as funeral ceremony at a time of enrollment of the study animals, and calves that were not born in selected Kebeles were excluded from the study.

2.4. Sample Size Determination and Sampling Procedure. To determine the number of households to be enrolled in the study from the district, the mathematical model of [29] was used. The sample size, $N$, can then be expressed as largest integer less than or equal to $0.25 / \mathrm{SE}^{2}$.

$$
N=\frac{0.25}{\mathrm{SE}^{2}},
$$

where SE is the standard error.

By considering SE of 0.0408 with $95 \%$ coefficient interval, $N=0.25 / 0.0408^{2}=150$. Hence, three Kebeles in the district were selected purposively based on the availability of calves under six months of age, transportation access, the livestock-crop mixed production system, and the presumed cooperativeness of the owners. Then, fifty (50) households were targeted from each Kebele, and all calves within the household meeting the inclusion criteria during the sample collection period (December 2018 to April 2019) were included in the study. 


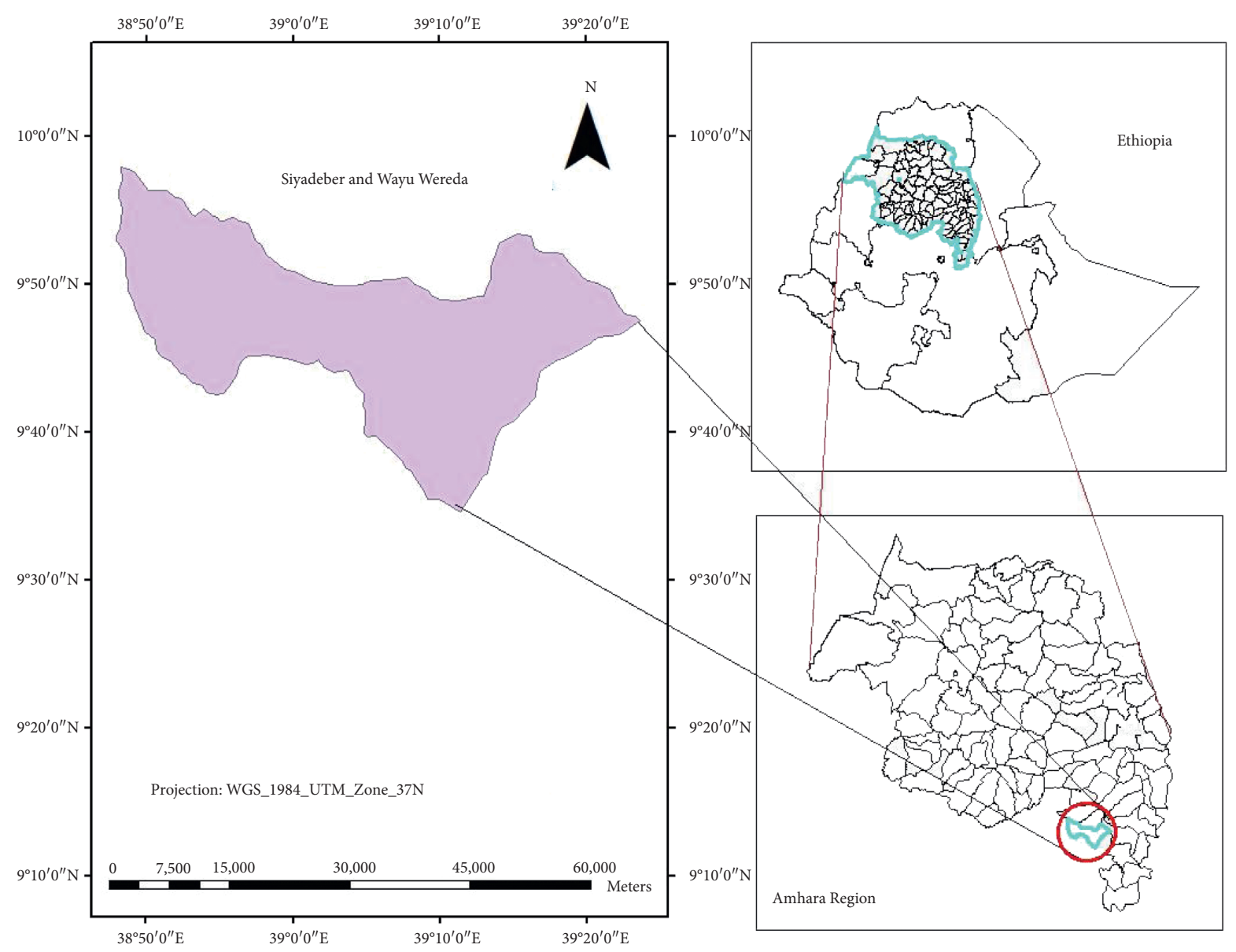

Figure 1: Map showing the study area, Siyadeber and Wayu District, North Shewa, Amhara region, Ethiopia, 2019.

To study the potential risk factors for calf morbidity among calves under six months of age, Epi info. V. 7, software was used to determine the sample size for a cohort study which was used with an assumption of; two-sided confidence level (1-alpha) (95\%), power (chance of detecting) (80\%), ratio of exposed (with the specific factor) to the nonexposed (without the factor of interest) (1), hypothetical proportion of morbidity with exposure, and hypothetical proportion of morbidity with nonexposure from previous research findings $[9,30]$ of related works. Then, the calculated sample size by Fleiss with continuity correction was considered, and the largest sample size was considered for this study. There was at least a total of 150 calves from 150 households. Then, the sample size was proportionally allocated for the three Kebeles (Gash-amba, Siyadeber, and Wale-deneba). However, a total of 135 calves that fulfilled the inclusion criteria were enrolled in the study (Figure 2).

2.5. Data Collection and Calf Health Monitoring. Firstly, the aim of the study was explained by insuring as the study will not cause any harm and are free to leave the study if they desire. Following this, verbal consent was obtained and the appropriateness of the study population was ascertained by physical and clinical examination techniques made on spot that included but not limited to rectal temperature, heart

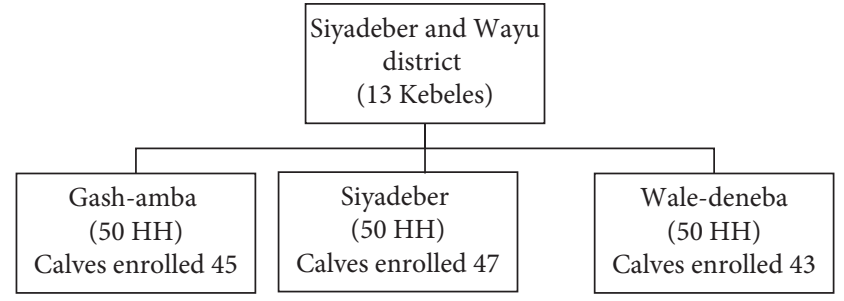

FIGURE 2: Schematic representation of sampling procedure for selecting study animal from Siyadeber and Wayu, North Shawa, Amhara regional state, Ethiopia, 2019.

rate, respiratory rate, color of mucous membranes, palpation of superficial lymph nodes, coughing (up on cough induction), rumen movements (where applicable), skin condition, joints and feet examination, depressed mentation, poor suckle reflex, weakness, and recumbence. Besides, external examination of the umbilicus followed by deep palpation of internal umbilical structures was made in lateral recumbence to identify a significant umbilical infection by rolling the 3 middle fingers of each hand ventrally off the abdominal musculature for any evidence of enlargement or pain. The skin elasticity was also evaluated by pinching a fold of skin over the lateral mid-cervical region, rotating it 90 degrees and determining the length of time (in seconds) it takes for the fold to disappear to determine the extent of 
hydration. Furthermore, the calves' health was assessed using objective criteria of appetite, fecal consistency, hydration status, and demeanor (Table 1). Subsequent to these evaluations, calves were designated as "normal" or "sick" [31]. Then, a structured pretested questionnaire was used to assess the determinant factors of calves morbidity by a face to face interview made with the owners who have close information about their calves.

Monitoring of households for the incidence of calf morbidity was carried out for 4 months in a weekly visit basis. A check-off format was used to capture the individual calf risk factors. On the first day of enrollment, information surrounding each calf, its feeding practice, bedding, including the herd health management practices was collected through the questionnaire. After the initial visit, every selected household was visited once per week until the end of the follow-ups, and individual record was kept afterwards. Clinical abnormalities were recorded on a separate sheet through the follow-up sheet prepared for the study. However, calves that reached six months of age or shown morbidity indicator were withdrawn from the follow-up.

In our study, young aged cattle, under six months of age were considered as calves. The term "Clean Calf pen" denotes the housing place of calf, which was noted clean by visualization at a time of visit for at least more than 8 visits from a total of 15 visits made. Those calf owners who answered correctly at least 8 questions from the 15 proposed questions that can assess knowledge regarding calf management practice were considered as owners with "good knowledge." Any abnormality that can be detected through physical and clinical examination such as calf with diarrhea, pneumonia, fever, and any comorbid conditions including calves with a poor body condition score was set to dictate morbidity.

Fecal samples were collected aseptically whenever a case of diarrhea was encountered for the identification of parasites and bacteria causing diarrhea after on-spot gross examination of the fecal samples. A duplicate fecal sample was then collected for both bacteriological and parasitological examination by using a sterile collecting tube and tubes with potassium dichromate, respectively. The sample was coded as it is appeared on the questionnaire format and labeled. Then, the samples were stored in cold chain and transported in an ice-box to National Animal Health Diagnostic and Investigation Center (NAHDIC) for processing. The samples were processed not beyond 2 days after sample collection following the standard procedures by wellexperienced laboratory experts. Standard methods were followed for isolation and identification of disease-causing agents: bacteria and parasites. Bacterial isolation from different specimens was employed by inoculation on different plates. Then, subsequent biochemical tests for indole test, methyl red test, Voges Proskauer test, citrate utilization (IMViC) test, hydrogen sulphide production test, and spot test for indole, which revealed the existence of diseases. Samples for bacterial isolation were conducted according to [32], whereas parasitological samples were processed using the methods employed by the authors [33].
2.6. Data Management and Analysis. The collected data from the study area were coded and entered into Microsoft excel and transported to STATA version 14 statistical software (STATA Corporation, College Station, USA) for data processing and analysis. Descriptive statistics such as mean and frequencies were used to present the summary of the studied variables with the cumulative morbidity rates. To evaluate the presence of association among the risk factors and calf morbidity chi-squire and Fisher's exact test were used. Furthermore, for the evaluation of strength of association, risk ratio with the respective confidence interval was estimated using the Generalized Linier Models for binomial family extensions for risk estimate. In addition, the respective morbidity rate was determined, and throughout the statistical analysis $p$ value $<0.05$ was considered as statistically significant.

\section{Results}

3.1. The Study Households and Dairy Calf Management Practices. The majority of respondents were male (84.6\%) and the rest $(15.4 \%)$ were female. As to the respondent's literacy rate, $69 \%$ of the household owners can read and write but did not complete primary and secondary school. The number of local and crossbreed calves in the households were $73(54 \%)$ and $62(46 \%)$. The livelihoods of the owners entirely depend on livestock production and agriculture, which is a mixed type of production system. Most of the respondents $(73.3 \%)$ had knowledge of the advantage of feeding colostrum to calves over ordinary milk and fed colostrum early within six hours of birth. About $88.8 \%$ and $71.1 \%$ household owners provided separate place of birth for pregnant cows and calf house bedding, respectively. However, others, $11.1 \%$ and $28.9 \%$, did not provide separate place of birth and calf house bedding, respectively (Table 2).

\subsection{Calves Morbidity}

3.2.1. Cumulative Incidence of Calves Morbidity. The overall occurrence of morbidity in calves of under six months of age was found to be $34.1 \%$ (95\% confidence interval (CI): 26.1-42.7\%), of which diarrhea was the most frequently observed $(34.82 \%)$ clinical disorder followed by respiratory signs (23.9\%) (Table 3 ).

From the total diarrhea samples taken, higher rate of Escherichia coli (93.75\%) was obtained, and none of them were positive for Salmonella species (Table 4).

3.2.2. Incidence Rate of Calves Morbidity. The total calves day at risk was 11847 days (394.9 months at risk or 32.46 years at risk), and the contribution of the calves with morbidity was 2965 days whereas that of calves without morbidity was 8882 days. The overall incidence rate of calf morbidity among under six months of age was 388 calves per 100,000 days of follow-up (Table 5).

The incidence rate of calf morbidity at Siyadeber Kebele were 556 calves per 100,000 days at risk than the 249 calves morbidity in Gash-amba Kebele's per 100,000 days at risk. 
TABLE 1: Criteria for designating a calf to either normal or with morbidity indicator (sick).

\begin{tabular}{|c|c|}
\hline Health condition & Clinical signs \\
\hline \multirow{2}{*}{ Diarrhea } & Formed to semiformed/normal \\
\hline & White or yellow/dark brown scours/watery/watery with mucus/blood stained \\
\hline \multirow{3}{*}{ Respiratory signs } & Normal \\
\hline & Rhinitis/coughing/heavy thoracic or abdominal breathing \\
\hline & Normal appearance \\
\hline \multirow{3}{*}{ Dehydration } & Mild (slightly depressed, eyeball recession of $2-4 \mathrm{~mm}$, and skin tent duration of $1-2$ seconds) \\
\hline & Moderate (depressed, eyeball recession of $4-6 \mathrm{~mm}$, and skin tent duration of $2-5$ seconds) \\
\hline & Sever (comatose/very depressed, eyeball recession of $6-8 \mathrm{~mm}$, and skin tent duration of 5-10 seconds) and above \\
\hline \multirow{2}{*}{ Attitude } & Alert/normal \\
\hline & Depressed/nonresponsive \\
\hline \multirow{2}{*}{ Appetite } & Normal \\
\hline & Absence of prolonged hunger and or thirst/reduced appetite/poor suckle response \\
\hline \multirow{2}{*}{ Eye appearance } & Normal \\
\hline & Swelling/redness/discharge \\
\hline \multirow{2}{*}{ Umbilicus/joints } & Normal \\
\hline & Swelling/heat/pain/lameness \\
\hline \multirow{2}{*}{ Otitis } & Normal \\
\hline & Head tilt, hanging head \\
\hline
\end{tabular}

TABle 2: Frequency distribution of the calves among the study variables at Siyadeber and Wayu District, North Shewa, Amhara region, Ethiopia $(n=135)$.

\begin{tabular}{|c|c|c|c|}
\hline Determinant factors & Category & Number of calves & Frequency (\%) \\
\hline \multirow{3}{*}{ Kebele } & Gash-amba & 45 & 33.3 \\
\hline & Wale-deneba & 43 & 31.9 \\
\hline & Siyadeber & 47 & 34.8 \\
\hline \multirow{2}{*}{ Breed } & Local & 73 & 54.1 \\
\hline & Cross & 62 & 45.9 \\
\hline \multirow{2}{*}{ Age } & $<3$ month & 98 & 72.6 \\
\hline & $\geq 3$ month & 37 & 27.4 \\
\hline \multirow{2}{*}{ Sex } & Female & 67 & 49.6 \\
\hline & Male & 68 & 50.4 \\
\hline \multirow{2}{*}{ Place of birth } & Same area as herd & 15 & 11.1 \\
\hline & Separate area & 120 & 88.9 \\
\hline \multirow{2}{*}{ Sire used } & Artificial insemination & 40 & 29.6 \\
\hline & Bull & 95 & 70.4 \\
\hline \multirow{2}{*}{ Type of delivery } & Not assisted & 38 & 28.1 \\
\hline & Assisted & 97 & 71.9 \\
\hline \multirow{2}{*}{ Calves housed with dam } & No & 114 & 84.4 \\
\hline & Yes & 21 & 15.6 \\
\hline \multirow{2}{*}{ Calves housed with other livestock's } & No & 129 & 95.6 \\
\hline & Yes & 6 & 4.4 \\
\hline \multirow{2}{*}{ Calves fed supplemental food } & No & 21 & 15.6 \\
\hline & Yes & 114 & 84.4 \\
\hline \multirow{2}{*}{ Housed bedding } & No & 39 & 28.9 \\
\hline & Yes & 96 & 71.1 \\
\hline \multirow{2}{*}{ Colostrum feeding time interval } & $1-6 \mathrm{hr}$ & 99 & 73.3 \\
\hline & $6-12 \mathrm{hr}$ & 36 & 26.7 \\
\hline \multirow{3}{*}{ Age at parturition of their dam } & Heifers $(3-4 \mathrm{yr})$ & 77 & 57.0 \\
\hline & Cow (4-8 yrs) & 12 & 8.9 \\
\hline & Older cows $(>8$ yrs $)$ & 46 & 34.1 \\
\hline \multirow{3}{*}{ Parity of their dam } & $1^{\text {st }}$ parity & 32 & 23.7 \\
\hline & $2^{\text {nd }}-4^{\text {th }}$ parity & 61 & 45.2 \\
\hline & $>4^{\text {th }}$ parity & 42 & 31.1 \\
\hline \multirow{2}{*}{ Calves pen cleaning condition } & Not clean & 25 & 18.5 \\
\hline & Clean well & 110 & 81.5 \\
\hline \multirow{2}{*}{ Calves feed type } & Only milk & 98 & 72.6 \\
\hline & Other feed + milk & 37 & 27.4 \\
\hline \multirow{2}{*}{ Owners knowledge level } & Poor & 7 & 5.2 \\
\hline & Good & 128 & 94.8 \\
\hline
\end{tabular}


TABLe 3: Cumulative incidence of calves morbidity with their respective morbidity indicators $(n=135)$.

\begin{tabular}{lccc}
\hline Cave morbidity indicators & Calves with morbidity & Within morbidity percentage & Cumulative incidence, (95\% CI) \\
\hline Diarrhea & 16 & 34.8 & $11.8(6.9-18.5)$ \\
Dehydration & 6 & 13.0 & $4.4(1.6-9.4)$ \\
Pneumonia & 11 & 23.9 & $8.1(4.1-14.1)$ \\
Navel ill & 4 & 8.7 & $3.0(0.8-7.4)$ \\
Septicemia & 9 & 19.6 & $6.7(3.1-12.3)$ \\
Total & $\mathbf{4 6}$ & $\mathbf{1 0 0 . 0}$ & $\mathbf{3 4 . 1}(\mathbf{2 6 . 1 - 4 2 . 7 )}$ \\
\hline
\end{tabular}

TABle 4: Types of pathogens isolated from fecal samples of calf with diarrhea at Siyadeber and Wayu District, North Shewa, Amhara region, Ethiopia.

\begin{tabular}{lcc}
\hline Type of pathogens isolated & Number positive & Proportion of pathogens from 16 diarrhea cases \\
\hline Escherichia coli & 15 & $93.75 \%$ \\
Salmonella species & 0 & 0 \\
Coccidia egg & 13 & $81.25 \%$ \\
Haemonchus & 2 & $12.5 \%$ \\
Mixed infection (Escherichia coli and Coccidia egg) & 4 & $25 \%$ \\
\hline
\end{tabular}

TABLE 5: Calves morbidity rate across the morbidity indicators $(n=135)$.

\begin{tabular}{lcccc}
\hline $\begin{array}{l}\text { Morbidity } \\
\text { indicators }\end{array}$ & $\begin{array}{c}\text { Number of calves with clinical } \\
\text { signs }\end{array}$ & Per calves & \multicolumn{2}{c}{$\begin{array}{c}\text { Incidence rate of calf morbidity } \\
\text { Per calves-month at } \\
\text { risk }\end{array}$} \\
\hline Diarrhea & 16 & 135 & 0.040517 & $\begin{array}{c}\text { Per calves-years at } \\
\text { risk }\end{array}$ \\
Dehydration & 6 & 50 & 0.015194 & 0.492914 \\
Respiratory signs & 11 & 93 & 0.027855 & 0.184843 \\
Navel ill & 4 & 34 & 0.010129 & 0.338879 \\
Septicemia & 9 & 76 & 0.022791 & 0.123229 \\
Total case & 46 & 388 & 0.116485 & 0.277264 \\
\hline
\end{tabular}

The incidence rate of calves that were housed with their dam, calves housed with other livestock, calves with no bedding house, and cows at an age of 4 to 8 years were with a higher incidence rate than their counterparts (Table 6).

Calves from Siyadeber Kebele were 2.11 times at a higher risk of facing morbidity than calves from Gash-amba Kebele. Form the calf-related factors, calves that housed with other livestock, housed with their dam, and calves without bedding were nearly two times at risk of encountering morbidity than their counterparts. Calves whose dam age ranges from 5 to 8 years were also 1.87 times more likely to encounter morbidity than calves whose dam age was between 3 to 4 years (Table 7).

\section{Discussion}

The present study was conducted to determine the incidence of calf morbidity and also to investigate the underlining risk factors in the selected 150 households at siyadeber and wayu district.

The present study established an overall cumulative incidence of $34.1 \%(46 / 135)$ calf morbidity, in which diarrhea take the leading cause of calf morbidity followed by pneumonia, septicemia conditions, dehydration, and navel ill. The magnitude of crude morbidity reported in this study agrees with the finding of [30], which reported $29.3 \%$ of the crude morbidity rate. However, it is lower than that of other reports from abroad $[34,35]$, which reported $52 \%$ morbidity rate in dairy calves and many previous reports in Ethiopia which is $62 \%, 58.4 \%$, and $47.3 \%$ as reported in $[8,9]$, respectively. This difference might be due to variations in calf and herd-level risk factors, management practices, age of the calf considered, breed of study calves, and agroecology. For instance, most previous reports from Ethiopia were based on studies in research stations and government ranches with large herd sizes, usually owning high exotic blood level animals that are usually known to increase the risk of calf morbidity [36]. However, the present study was conducted in the households with a small number of calves per household (an average of 0.9 calf), that makes farmers to easily monitor their calves and take early preventive measures to elude calf health problems.

The incidence of calf diarrhea in the present study was $11.8 \%$, and it is comparable with the incidence rate report of $[37,38]$ from North Western Ethiopia. In contrary to this, the present finding is less than previous studies $[8,9]$ which reported $42.9 \%$ and $34 \%$, respectively. The difference can be caused by many factors including variation in ingestion of colostrums, hygienic condition of feeding utensils, and condition of housing [39]. This finding has also been supported by other studies [18, 36, 40], which explained that diarrhea is the commonest disease and the greatest single cause of neonatal mortality during the first week of life. Calf diarrhea accounts for approximately $75 \%$ of the mortality of 
TABLE 6: Incidence of calf morbidity among the identified predictors of calf morbidity at Siyadeber and Wayu District, North Shawa, Amhara region, Ethiopia.

\begin{tabular}{|c|c|c|c|c|}
\hline \multirow[b]{2}{*}{ Determinant factors } & \multirow[b]{2}{*}{ Category } & \multicolumn{3}{|c|}{ Calf morbidity } \\
\hline & & Cases with morbidity & Calf-days at risk & $\begin{array}{c}\text { Incidence rate of calf morbidity } \\
\text { per } 100,000 \text { days at risk }\end{array}$ \\
\hline \multirow{3}{*}{ Study areas (kebele) } & Gash-amba & 10 & 4010 & 249 \\
\hline & Wale-deneba & 14 & 3883 & 360 \\
\hline & Siyadeber & 22 & 3954 & 556 \\
\hline \multirow{2}{*}{ Calves housed with dam } & No & 34 & 10093 & 337 \\
\hline & Yes & 12 & 1754 & 684 \\
\hline \multirow{2}{*}{ Calves housed with other livestock } & No & 42 & 11403 & 368 \\
\hline & Yes & 4 & 444 & 901 \\
\hline \multirow{2}{*}{ Housed bedding } & No & 20 & 3054 & 655 \\
\hline & Yes & 26 & 8793 & 296 \\
\hline \multirow{3}{*}{ Age at parturition of their dam } & Heifers (3-4 yr) & 24 & 6920 & 345 \\
\hline & Cow (4-8 yrs) & 7 & 817 & 857 \\
\hline & Older cows ( $>8 \mathrm{yrs})$ & 15 & 4110 & 365 \\
\hline
\end{tabular}

TABLE 7: Bivariate analysis result for the potential risk factors associated with calves at Siyadeber and Wayu District, North Shewa, Amhara region, Ethiopia.

\begin{tabular}{|c|c|c|c|c|c|c|}
\hline \multirow{2}{*}{ Determinant factors } & \multirow{2}{*}{ Category } & \multicolumn{3}{|r|}{ Morbidity } & \multirow{2}{*}{$\mathrm{RR}(95 \% \mathrm{CI})$} & \multirow{2}{*}{$p$ value } \\
\hline & & Yes & No & Total calves followed-up & & \\
\hline \multirow{3}{*}{ Kebele } & Gash-amba & 10 & 35 & 45 & 1.00 & \\
\hline & Wale-deneba & 14 & 29 & 43 & $1.46(0.73-2.94)$ & 0.282 \\
\hline & Siyadeber & 22 & 25 & 47 & $2.11(1.13-3.94)$ & 0.020 \\
\hline \multirow{2}{*}{ Place of birth } & Separate area & 3 & 12 & 15 & 1.00 & \\
\hline & Same area & 43 & 77 & 120 & $1.79(0.63-5.07)$ & 0.272 \\
\hline \multirow{2}{*}{ Calves housed with dam } & No & 34 & 80 & 114 & 1.00 & \\
\hline & Yes & 12 & 9 & 21 & $1.92(1.20-3.05)$ & 0.006 \\
\hline \multirow{2}{*}{ Calves housed with other livestock } & No & 42 & 87 & 129 & 1.00 & \\
\hline & Yes & 4 & 2 & 6 & $2.05(1.10-3.80)$ & 0.023 \\
\hline \multirow{2}{*}{ Housed bedding } & No & 20 & 19 & 39 & $1.89(1.20-2.94)$ & 0.006 \\
\hline & Yes & 26 & 70 & 96 & 1.00 & \\
\hline \multirow{3}{*}{ Age at parturition of their dam } & Heifers $(3-4$ yr) & 24 & 53 & 77 & 1.00 & \\
\hline & Cow (5-8 yrs) & 7 & 5 & 12 & $1.87(1.05-3.35)$ & 0.035 \\
\hline & Older cows $(>8 \mathrm{yrs})$ & 15 & 31 & 46 & $1.04(0.61-1.78)$ & 0.868 \\
\hline \multirow{3}{*}{ Parity of their dam } & $1^{\text {st }}$ & 14 & 18 & 32 & 1.00 & \\
\hline & $2^{\text {nd }}-4^{\text {th }}$ & 16 & 45 & 61 & $0.60(0.34-1.07)$ & 0.082 \\
\hline & $>4^{\text {th }}$ & 16 & 26 & 42 & $0.87(0.50-1.51)$ & 0.622 \\
\hline \multirow{2}{*}{ Calves pen cleaning condition } & Not clean & 5 & 20 & 25 & 1.00 & \\
\hline & Clean well & 41 & 69 & 110 & $1.86(0.82-4.23)$ & 0.137 \\
\hline \multirow{2}{*}{ Farmers owners knowledge level } & Poor & 22 & 35 & 57 & 1.00 & \\
\hline & Good & 24 & 54 & 78 & $0.80(0.50-1.27)$ & 0.341 \\
\hline
\end{tabular}

dairy calves aged below three weeks of age [41]. Furthermore, these findings are consistent with the reports of [16] in Ethiopia and many other studies elsewhere, which reported diarrhea and pneumonia as the first and second important disease complexes that affect calf health $[17,18,35]$. However, there are also some contradictory reports that detail pneumonia as the leading calf health problem [7]. The reason why diarrhea is the predominant cause of calf morbidity might be due to poor hygienic handling of feeding utensils, calving area, and calf pen. All these managerial factors might be incriminated in the high incidence of calf diarrhea reported by the present study and in many previous reports.
The relatively lower incidence of pneumonia in this study might be due to the small herd size of the households. Since large herd size has strong correlation with environmental stress that exposes calves to respiratory problems [36], it was observed that a 50\% decrease in stocking density was increasing the ventilation rate by 20 times thereby decreasing the risk of pneumonia [41]. Of total omphalitis cases, $62.5 \%$ was recorded in the first weeks of life. This finding is consistent with [34], which reported the incidence of umbilical infection is usually common in the first week of life and within 2-5 days after the birth of calf, respectively. The incidence rates of other calf health problems were found lower than those of diarrhea and pneumonia in this study. 
From the hypothesized explanatory variables tested for their association with calf morbidity, parturition age of the dam, calf bedding availability, and calves housed with other livestock were significantly associated with calf morbidity. This finding is in agreement with previous reports $[15,36,42]$ which indicate that parity of the dam contributes to the occurrence of E. coli-associated septicemia. These could be attributed to the lower in immunoglobulin (Ig) content of heifer's colostrum than older cows, and therefore colostrum deprived calves are highly susceptible to colisepticemia. Furthermore, older cows tend to have more IgG than first calf heifers, as they have been exposed to a greater number of pathogens during their lifetimes. Therefore, as to the present and previous reports, these could contribute to overall increase in calf morbidity rate.

Unlike most of the previously reported studies [7, $17,30,35,36,43-48]$, age, sex, and breed of calves as well as management-related risk factors like colostrum feeding time, calves pen cleaning, place of birth, feed type, and frequency of calves are nonsignificantly associated with the incidence of morbidity. This could be due to the good calf caring practice and relatively good knowledge of the household owners observed in calf management practice in the study setup, in which $58 \%$ owners correctly answered above the mean of the prepared knowledge based questions. The discrepancy with the current finding may also relate with the differences in agroecology, management types, and husbandry practices of the study animals in different countries.

\section{Conclusions}

The present study found that the existence of high calf morbidity rate in Siyadeber and Wayu district. Calf diarrhea was predominant calf health problem followed by pneumonia, septicemia, dehydration, and navel ill, respectively. Among the potential risk factors investigated, age of dam at parturition, parity number, calf house bedding, and calves housed with dam and calves housed with other livestock were found significantly associated with crude morbidity. Therefore, attention must be given to proper management, hygienic conditions, and improved health care of calves to minimize morbidity. Thus, calves pen should be clean, well bedded, and must not be housed together with other livestock. Beside, we suggest a more comprehensive study that indicates the major infectious causes of disease of calf such as diarrhea and pneumonia.

\section{Data Availability}

The datasets used and/or analyzed during the current study are available from the corresponding author on reasonable request.

\section{Conflicts of Interest}

The authors declare that they have no conflicts of interest.

\section{Acknowledgments}

The authors would like to extend their deepest appreciation to their study participants for their willingness to participate in the study and allowing us to conduct our study on their calves management system. The authors are grateful to the National Animal Health Diagnostic and Investigation Center (NAHDIC) located at Sebeta, Ethiopia, for the support given to undertake the full laboratory work. The authors received no specific funding for this work.

\section{References}

[1] CSA (Central Statistics Agency), "Report on livestock and livestock characteristics, agricultural sample survey," Central Statistical Agency, Addis Ababa, Ethiopia, 2017.

[2] R. Behnke and F. Metaferia, "The contribution of livestock to the Ethiopian economy-part II," IGAD Livestock Policy Initiative, Eritrea, Ethiopia, IGAD LPI Working Paper No. 02$11,2011$.

[3] NABC (Netherlands-African Business Council), "Livestock in Ethiopia and opportunity analysis for Dutch investment," NABC (Netherlands-African Business Council), Hague, The Netherlands, Fact Sheet: Livestock Ethiopia, 2010.

[4] S. Ayele, W. Assegid, M. A. Workalemahu, M. Jabbar, M. Ahmed, and H. Belachew, "Livestock marketing in Ethiopia: a review of structure, performance and development initiatives," Socio-Economic and Policy Research. Livestock Marketing Authority, the Federal Democratic Republic of Ethiopia, Addis Ababa, Ethiopia, International Livestock Research Institute, Nairobi, Kenya, 2003.

[5] Y. Ferede, "Epidemiology of gastrointestinal helminthiasis of crossbred calves in selected sites of Bahir Dar Zuria and Gozamen districts of Amhara region, northwest Ethiopia," International Journal of Pharmacy And Biological Sciences, vol. 2, no. 3, pp. 18-27, 2013.

[6] J. S. Changa, R. H. Mdegela, R. Ryoba, T. Loken, and O. Reksen, "Calf health and management in smallholder dairy farms in Tanzania," Tropical Animal Health and Production, vol. 42, pp. 1669-1676, 2010.

[7] Y. Shiferaw, A. Yohannes, Y. Yilma, A. Gebrewold, and Y. Gojjam, "Dairy husbandry and health management at Holleta," in Proceeding of the 16th Conference of the Ethiopian Veterinary Association, pp. 103-119, Addis Ababa, Ethiopia, June 2002.

[8] T. Wudu, B. Kelay, H. M. Mekonnen, and K. Tesfu, "Calf morbidity and mortality in smallholder dairy farms in Ada'a Liben district of Oromia, Ethiopia," Tropical Animal Health and Production, vol. 40, no. 5, pp. 369-376, 2008.

[9] Y. Ferede, H. Mazengia, T. Bimrew, A. Bitew, M. Nega, and A. Kebede, "Pre-weaning morbidity and mortality of crossbred calves in Bahir Dar Zuria and Gozamen districts of Amhara region, northwest Ethiopia," Open Access Library Journal, vol. 1, p. e6000, 2014.

[10] O. M. Radostits, C. C. Gay, K. W. Hinchcliff, and P. D. Constable, Veterinary Medicine: A Textbook of the Diseases of Cattle, Sheep, Pigs, Goats and Horses, Saunders Elsevier, Philadelphia, PA, USA, 10th edition, 2010.

[11] AACM (Australian Agricultural Consulting and Management), Project Preparation Report: Dairy Rehabilitation and Development Project Annexes, AACM Co. Ltd., Chicago, IL, USA, 1985.

[12] G. H. Arthur, D. E. Noakes, and H. Person, Veterinary Reproduction and Obstetrics, Baillier Tindall, Waltham, MA, USA, 6th edition, 1989.

[13] E. Mukasa-Mugerwa, "A review of reproductive performance of female Bos indicus (zebu) cattle," Monograph No. 6, ILCA, 
pp. 101-104, International Livestock Centrefor Africa, Addis Ababa, Ethiopia, 1989.

[14] M. N. Wymann, B. Bonfoh, E. Schelling et al., "Calf mortality rate and causes of death under different herd management systems in peri-urban Bamako, Mali," Livestock Science, vol. 100, no. 2-3, pp. 169-178, 2006.

[15] M. T. Admasu and D. J. Hassen, "Major management and health problems of calves in smallholder dairy farms in selected areas of Dugda Bora, Arsi Negelle, Shashemene and Kofelle Woredas," Journal of Veterinary Science \& Technology, vol. 7, no. 4, p. 351, 2016.

[16] M. Lemma, T. Kassa, and T. Tegegne, "Clinically manifested major health problems of crossbred dairy herds in urban and peri-urban production systems in the central highlands of Ethiopia," Tropical Animal Health and Production, vol. 33, no. 2, pp. 85-93, 2001.

[17] S. O. Olsson, S. Viring, U. Emanuelsson, and S. O. Jacobsson, "Calf diseases and mortality in Swedish dairy herds," Acta Veterinaria Scandinavica, vol. 34, no. 34, pp. 263-269, 1993.

[18] N. J. Sivula, T. R. Ames, W. E. Marsh, and R. E. Werdin, "Descriptive epidemiology of morbidity and mortality in Minnesota dairy heifer calves," Preventive Veterinary Medicine, vol. 27, no. 3-4, pp. 155-171, 1996.

[19] C. Svensson, A. Linder, and S.-O. Olsson, "Mortality in Swedish dairy calves and replacement heifers," Journal of Dairy Science, vol. 89, no. 12, pp. 4769-4777, 2006.

[20] J. E. Lombard, F. B. Garry, S. M. Tomlinson, and L. P. Garber, "Impacts of dystocia on health and survival of dairy calves," Journal of Dairy Science, vol. 90, no. 4, pp. 1751-1760, 2007.

[21] S. M. Gulliksen, K. I. Lie, T. Løken, and O. Østerås, "Calf mortality in Norwegian dairy herds," Journal of Dairy Science, vol. 92, no. 6, pp. 2782-2795, 2009.

[22] M. Azizzadeh, H. F. Shooroki, A. S. Kamalabadi, M. A. Stevenson, A. Mark, and K. Stevenson, "Factors affecting calf mortality in Iranian Holstein dairy herds," Preventive Veterinary Medicine, vol. 104, no. 3-4, pp. 335-340, 2012.

[23] A. C. Barrier, M. J. Haskell, S. Birch et al., "The impact of dystocia on dairy calf health, welfare, performance and survival," The Veterinary Journal, vol. 195, no. 1, pp. 86-90, 2013.

[24] M. C. Windeyer, K. E. Leslie, S. M. Godden, D. C. Hodgins, K. D. Lissemore, and S. J. LeBlanc, "Factors associated with morbidity, mortality, and growth of dairy heifer calves up to 3 months of age," Preventive Veterinary Medicine, vol. 113, no. 2, pp. 231-240, 2014.

[25] J. Margerison and N. Downey, "Guidelines for optimal dairy heifer rearing and herd performance," in Calf and Heifer Rearing-Principles of Rearing the Modern Dairy Heifer, P. C. Garnsworthy, Ed., Nottingham University Press, Nottingham, UK, 2005.

[26] M. Hailemariam, G. Mekonnen, and A. Beker, "Pre-weaning performance of fogera calves and their Friesian crosses in North-Western Ethiopia," World Review of Animal Production, vol. 28, pp. 61-66, 1993.

[27] B. Asseged and M. Birhanu, "Survival analysis of calves and reproductive performance of cows in commercial dairy farms in and around Addis Ababa, Ethiopia," Tropical Animal Health and Production, vol. 36, no. 7, pp. 663-672, 2004.

[28] DOA (Department of Agriculture), Annual Progress Reports. Siyadeber and Wayu Wereda Ethiopia, DOA (Department of Agriculture), Washington, DC, USA, 2019.

[29] H. Arsham, "Questionnaire design and survey sampling," 2005, http://homeubalt.edu/ntsbarsh/stat-data/surveys.htm.
[30] B. Megersa, Y. Abduba, R. Alemayehu, A. Fufa, A. Kassahun, and A. kebede, "Prevalence and incidence rates of calf morbidity and mortality and associated risk factors in smallholder dairy farms in Hawassa, Southern Ethiopia," Ethiopian Veterinary Journal, vol. 13, pp. 59-68, 2009.

[31] A. C. B. Berge, P. Lindeque, D. A. Moore, and W. M. Sischo, "A clinical trial evaluating prophylactic and therapeutic antibiotic use on health and performance of preweaned calves," Journal of Dairy Science, vol. 88, no. 6, pp. 2166-2177, 2005.

[32] P. J. Quinn, M. E. Carter, B. K. Markey, and G. R. Carter, Clinical Veterinary Microbiology, Mosby Publication, St. Louis, MO, USA, 1994.

[33] J. Hansen and B. Perry, A Handbook: The Epidemiology, Diagnosis and Control of Helminth Parasite of Ruminants, International Laboratory for Research on Animal Diseases Nairobi, Nairobi, Kenya, 1994.

[34] A. M. Virtala, G. D. Mechor, Y. Y. Grohn, and H. N. Erb, "Morbidity from non-respiratory disease and mortality in dairy heifers during the first three months of life," American Journal of Veterinary Research, vol. 208, pp. 2043-2046, 1996.

[35] N. C. Debnath, B. K. Sil, S. A. Selim, M. A. M. Prodhan, and M. M. R. Howlader, "A retrospective study of calf mortality and morbidity on smallholder traditional farms in Bangladesh," Preventive Veterinary Medicine, vol. 9, no. 1, pp. 1-7, 1990.

[36] T. Wudu, Calf Morbidity and Mortality in Dairy Farms in Debre Zeit and Its Envirions, Ethiopia, M. S. thesis, Faculty of Veterinary Medicine, Addis Ababa University, Addis Ababa, Ethiopia, 2004.

[37] A. A. Asmare and W. A. Kiros, "Dairy calf morbidity and mortality and associated risk factors in Sodo town and its Suburbs, Wolaita zone. Ethiopia," Slovak Journal of Animal Science, vol. 49, no. 1, pp. 44-56, 2016.

[38] G. Darsema, "Major causes of calf mortality in dairy farm and two cattle ranches in Western region, North Western Ethiopia," Ethiopian Veterinary Journal, vol. 12, pp. 59-68, 2008.

[39] K. Mengesha, E. B. Gurmu, and D. Hussein, "Major management and health problems of calves in dairy farms in and around Mekelle," Revista Electrónica de Veterinaria, vol. 14, no. 2, 2013.

[40] S. K. M. A. Islam, M. A. Hoque, M. R. Alam, M. M. Hassan, and M. A. Rahman, "A cross-sectional study on production performance of stall fed dairy cattle at Central cattle Breeding Station (CCBS), Savar, Dhaka," Bangladesh Journal of Veterinary Medicine, vol. 4, no. 1, pp. 61-63, 2006.

[41] R. W. Blowey, Veterinary Book for Dairy Farmers, Farming Press Ltd, Ipswich, UK, 2nd edition, 1990.

[42] T. Mebrahtu and D. Kebede, "Bacteriological study of calf coli septicemia in alage dairy farm, Southern Ethiopia," BMC Research Notes, vol. 10, p. 710, 2017.

[43] A. Amuamuta, B. Asseged, and G. Goshu, "Mortality analysis of Fogera calves and their Friesian crosses in Andassa cattle breeding and improvement ranch. Northwestern Ethiopia," Revue de Médecine Vétérinaire, vol. 157, no. 11, pp. 525-529, 2006.

[44] U. Bleul, "Risk factors and rates of perinatal and postnatal mortality in cattle in Switzerland," Livestock Science, vol. 135, no. 2-3, pp. 257-264, 2011.

[45] M. Konjit, B. Endale, and H. Dek, "Major management and health problems of calves in dairy farms in and around Mekelle," Revista Electronica de Veterinaria, vol. 14, no. 2, pp. 1-13, 2013. 
[46] M. Mellado, E. Lopez, F. G. Veliz et al., "Factors associated with neonatal dairy calf mortality in a hot-arid environment," Livestock Science, vol. 159, pp. 149-155, 2014.

[47] T. Yibrah and B. Tsega, "Cross-sectional study on calf health and management problems on small scale dairy farms of Sidama and Gedio zones, Southern Ethiopia," Journal of Veterinary Science \& Medicine, vol. 5, no. 1, p. 5, 2017.

[48] E. S. Swai, E. D. Karimuribo, and D. M. R. Kambarage, "Risk factors for smallholder dairy cattle mortality in Tanzania," Journal of the South African Veterinary Association, vol. 81, pp. 241-246, 2010. 